\title{
Estimating Preference Heterogeneity for Grass-fed Beef Cattle Traits - Addendum
}

\section{Isaac Sitienei, Jeffrey Gillespie, Robert W. Harrison, and Guillermo Scaglia}

DOI: https://doi.org/10.1017/age.2019.14. Published by Cambridge University Press 25 September 2019

The authors of this article (Sitienei et al. 2019) would like to add the following acknowledgments section to their article:

The findings and conclusions in this publication are those of the author(s) and should not be construed to represent any official USDA or U.S. Government determination or policy. This research was supported in part by the U.S. Department of Agriculture, Economic Research Service. The authors also acknowledge funding from the National Institute of Food and Agriculture / Agriculture and Food Research Initiative (2011-67023-30098) and U.S. Department of Agriculture Hatch funds (LAB 4178). The survey was conducted when the authors were employed by the Louisiana State University Agricultural Center.

\section{Reference}

Sitienei, I., Gillespie, J., Harrison, R.W., and Scaglia, G. 2019. "Estimating Preference Heterogeneity for Grass-fed Beef Cattle Traits." Agricultural and Resource Economics Review. DOI: https://doi.org/10.1017/age.2019.14

Agricultural and Resource Economics Review 48/3 (December 2019) 533

(C) The Author(s) 2019. This is an Open Access article, distributed under the terms of the Creative Commons Attribution licence (http://creativecommons.org/licenses/by/4.0/), which permits unrestricted re-use, distribution, and reproduction in any medium, provided the original work is properly cited. 